\title{
Deposition and doping of silicon carbide by gas-source molecular beam epitaxy
}

\author{
R. S. Kern ${ }^{\text {a) }}$ and R. F. Davis ${ }^{\text {b) }}$ \\ Department of Materials Science and Engineering, North Carolina State University, Raleigh, \\ North Carolina 27695-7907
}

(Received 3 March 1997; accepted for publication 3 July 1997)

\begin{abstract}
Thin films of silicon carbide ( $\mathrm{SiC}$ ) have been deposited at $1400-1450{ }^{\circ} \mathrm{C}$ on vicinal and on-axis $6 \mathrm{H}-\mathrm{SiC}(0001)$ substrates by gas-source molecular beam epitaxy using the $\mathrm{SiH}_{4}-\mathrm{C}_{2} \mathrm{H}_{4}-\mathrm{H}_{2}$ gas system. Polytype control $(6 \mathrm{H}$ - or $3 \mathrm{C}-\mathrm{SiC})$ was established by utilizing substrates of particular orientations. Residual, unintentionally incorporated nitrogen impurity levels were affected by changing the $\mathrm{SiH}_{4} / \mathrm{C}_{2} \mathrm{H}_{4}$ gas flow ratio, in agreement with the "site-competition epitaxy" model. In situ doping was achieved by intentional introduction of nitrogen and aluminum into the growing crystal. (C) 1997 American Institute of Physics. [S0003-6951(97)01836-6]
\end{abstract}

The extremes in the thermal and electronic properties of wide-band-gap semiconductors make possible many current and conceivable applications. Silicon carbide is one of the most studied of these materials. About 250 different polytypes have been reported. ${ }^{1}$ The sole cubic (zinc-blende) structure $(\beta$ - or $3 \mathrm{C}$-SiC) has a room-temperature energy band gap of $2.3 \mathrm{eV}$. Among the hexagonal and rhombohedral polytypes $(\alpha-\mathrm{SiC})$ the most common is $6 \mathrm{H}-\mathrm{SiC}$ with a roomtemperature band gap of $\approx 3.0 \mathrm{eV}$. Single-crystal epilayers of $3 \mathrm{C}$ - and $6 \mathrm{H}-\mathrm{SiC}$ can be homoepitaxially deposited via various vapor phase epitaxial growth procedures.

Previous $\mathrm{SiC}$ film growth studies via molecular beam epitaxy (MBE) on $6 \mathrm{H}-\mathrm{SiC}$ substrates at growth temperatures which were lower $\left(<1200^{\circ} \mathrm{C}\right)$ than those typically used in chemical vapor deposition (CVD) reportedly did not result in homoepitaxial reproduction of the $6 \mathrm{H}$ substrate. Recently, we have reported ${ }^{2}$ the first deposition of $6 \mathrm{H}-\mathrm{SiC}(0001)$ epilayers by gas-source MBE (GSMBE) at $T \geqslant 1350{ }^{\circ} \mathrm{C}$ using $\mathrm{SiH}_{4}-\mathrm{C}_{2} \mathrm{H}_{4}-\mathrm{H}_{2}$. The only previous report of $\mathrm{SiC}$ doping by MBE was performed by Kaneda et al. ${ }^{3}$ who deposited B-doped films of $3 \mathrm{C}-\mathrm{SiC}(111)$ on on-axis $6 \mathrm{H}-\mathrm{SiC}\{0001\}$ at $1150-1400{ }^{\circ} \mathrm{C}$. $p$ - $n$ junction diodes between $p$-type $(p=1$ $\left.\times 10^{18} \mathrm{~cm}^{-3}\right) \quad 3 \mathrm{C}$-SiC $(111) \quad$ and $n$-type $(n=5.6$ $\left.\times 10^{16} \mathrm{~cm}^{-3}\right) 6 \mathrm{H}-\mathrm{SiC}(0001)$ exhibited breakdown fields of $6.7 \times 10^{5} \mathrm{~V} \mathrm{~cm}^{-1}$.

In this work, a previously described ${ }^{4}$ GSMBE system was employed to deposit and dope $3 \mathrm{C}$ - and $6 \mathrm{H}-\mathrm{SiC}$. The base pressure of the system was $\approx 10^{-9}$ Torr and the operating pressure was approximately $(1-4) \times 10^{-4}$ Torr silane $\left(\mathrm{SiH}_{4}\right)$, ethylene $\left(\mathrm{C}_{2} \mathrm{H}_{4}\right)$, and hydrogen $\left(\mathrm{H}_{2}\right)$ were used to grow the $\mathrm{SiC}$ at temperatures between 1400 and $1450{ }^{\circ} \mathrm{C}$. Films were doped $n$-type using $\mathrm{N}$ atoms introduced from either $\mathrm{NH}_{3}\left(300 \mathrm{ppm}\right.$ in $\mathrm{H}_{2}$ ) or molecular $\mathrm{N}_{2}$. $p$-type conductivity was achieved by incorporating $\mathrm{Al}$ evaporated from a standard MBE effusion cell. Table I lists the growth conditions.

Since previous studies by $\mathrm{CVD}^{5-8}$ have demonstrated the advantage of using $6 \mathrm{H}-\mathrm{SiC}(0001)$ crystals cut off-axis to assist in the homoepitaxial growth of the $6 \mathrm{H}$ polytype,

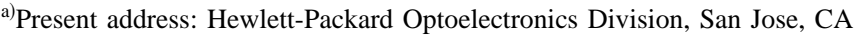
95131.

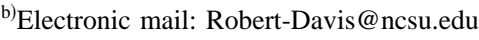

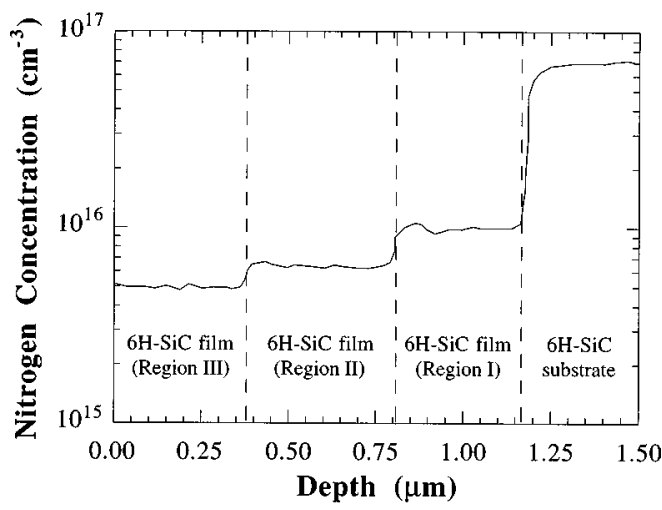

FIG. 1. SIMS profile of a $6 \mathrm{H}-\mathrm{SiC}(0001)$ films grown at $1400{ }^{\circ} \mathrm{C}$ with 0.75 sccm $\mathrm{SiH}_{4}, 5 \mathrm{sccm} \mathrm{H}_{2}$, and a variable $\mathrm{C}_{2} \mathrm{H}_{4}$ flow: $0.375 \mathrm{sccm}$ in Region I, $0.5 \mathrm{sccm}$ in Region II, and 0.75 in Region III. Note the changes in the nitrogen incorporation that resulted from changing the $\mathrm{C}_{2} \mathrm{H}_{4}$ input due to site-competition epitaxy between $\mathrm{C}$ and $\mathrm{N}$.

$\alpha(6 \mathrm{H})-\mathrm{SiC}(0001)$ substrates cut $3.5 \pm 0.5^{\circ}$ toward [11 $\left.\overline{2} 0\right]$ were the most common substrates used. On-axis $\alpha(6 \mathrm{H})$ $\mathrm{SiC}(0001)$ were also used, in cases where $\beta(3 \mathrm{C})-\mathrm{SiC}(111)$ was desired. Substrates were dipped in a $10 \%$ HF solution, loaded immediately into the growth chamber and cleaned in situ using a $\mathrm{SiH}_{4}$ exposure and UHV anneal. ${ }^{9}$

The epilayers were characterized using reflection highenergy electron diffraction (RHEED), secondary ion mass

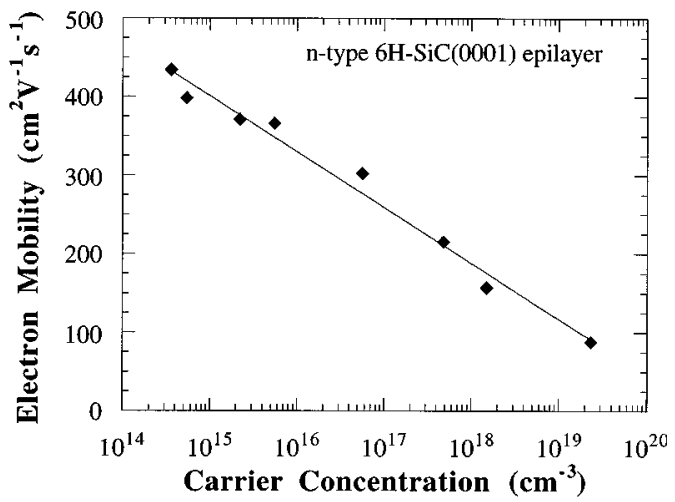

FIG. 2. Electron mobility vs carrier concentration for $n$-type $6 \mathrm{H}-\mathrm{SiC}(0001)$ epilayers. Measurements were performed at room temperature. The solid line is a guide for the eye. 
TABLE I. Range of growth parameters used in the course of this study.

\begin{tabular}{lccc}
\hline \hline & undoped & $n$-type doped & $p$-type doped \\
\hline Substrate & $6 \mathrm{H}-\mathrm{SiC}(0001)$ & $6 \mathrm{H}-\mathrm{SiC}(0001)$ & $6 \mathrm{H}-\mathrm{SiC}(0001)$ \\
Deposition pressure (Torr) & $\approx 2 \times 10^{-4}$ & $\approx 2 \times 10^{-4}$ & $\approx 2 \times 10^{-4}$ \\
Deposition temperature $\left({ }^{\circ} \mathrm{C}\right)$ & 1400 & 1400 & 1450 \\
$\mathrm{SiH}_{4}$ Flow rate $(\mathrm{sccm})$ & 0.75 & 0.75 & 0.75 \\
$\mathrm{C}_{2} \mathrm{H}_{4}$ flow rate $(\mathrm{sccm})$ & $0.375,0.5,0.75$ & 0.375 & 0.75 \\
$\mathrm{H}_{2}$ flow rate $(\mathrm{sccm})^{\mathrm{a}}$ & 5 & $0-5$ & 5 \\
$\mathrm{Al}$ cell temperature $\left({ }^{\circ} \mathrm{C}\right)$ & $\mathrm{N} / \mathrm{A}$ & $\mathrm{N} / \mathrm{A}$ & $770-1010$ \\
$\mathrm{NH}_{3}: \mathrm{H}_{2}$ flow rate $(\mathrm{sccm})^{\mathrm{a}, \mathrm{b}}$ & $\mathrm{N} / \mathrm{A}$ & $0-5$ & N/A \\
$\mathrm{N}_{2}$ flow rate $(\mathrm{sccm})^{\mathrm{b}}$ & $\mathrm{N} / \mathrm{A}$ & $0-5$ & N/A \\
\hline \hline
\end{tabular}

${ }^{\mathrm{a}}$ The total $\mathrm{H}_{2}+\mathrm{NH}_{3} \mathrm{H}_{2}$ flow rate was maintained at $5 \mathrm{sccm}$.

${ }^{b} n$-type doping was performed with either $\mathrm{NH}_{3}$ or $\mathrm{N}_{2}$.

spectroscopy (SIMS), mercury-probe capacitance-voltage $(C-V)$ analysis, and room-temperature Van der Pauw-Halleffect measurements. Special contact pads, ${ }^{9}$ produced by depositing heavily doped $\left(\approx 10^{18} \mathrm{~cm}^{-3}\right) \mathrm{SiC}$ through a shadow mask, were used to create ohmic contacts on undoped and lightly doped samples. All doped samples $(\approx 1 \mu \mathrm{m}$ in thickness) were grown on substrates of the opposite doping type in order to minimize parallel conduction phenomena.

Since even the most pure $\mathrm{SiC}$ grown from the vapor phase contains some quantity of $\mathrm{N}$, it was not surprising that the major contaminant in these films was $\mathrm{N}$. The presence of the $\mathrm{N}$ impurity is particularly significant, because it is the most shallow donor impurity in SiC. Consequently, it was the agent responsible for the $n$-type character of unintentionally doped SiC films. Although the growth rate measured at the temperatures and ambient conditions studied here was not observed to change when the $\mathrm{C}_{2} \mathrm{H}_{4}$ flow rate was modulated between 0.375 and $0.75 \mathrm{sccm}$ at a constant $\mathrm{SiH}_{4}$ flow rate $(0.75 \mathrm{sccm})$ considerable differences in the background atomic nitrogen and electron concentrations in the $\mathrm{SiC}$ films was measured. The background level of $\mathrm{N}$ was in accordance with the "site-competition epitaxy" model arguments ${ }^{10-13}$ based on the principle of competition between $\mathrm{C}$ and $\mathrm{N}$ for the $\mathrm{C}$ sites, and $\mathrm{Al}$ and $\mathrm{Si}$ for the $\mathrm{Si}$ sites in the $\mathrm{SiC}$ crystals. Thus, the $\mathrm{N}$ contamination level was significantly decreased by increasing the amount of $\mathrm{C}\left(\mathrm{C}_{2} \mathrm{H}_{4}\right)$ delivered in the gas phase.

Figure 1 shows a depth profiled $6 \mathrm{H}-\mathrm{SiC}(0001)$ film grown at $1400{ }^{\circ} \mathrm{C}$ using $0.75 \mathrm{sccm} \mathrm{SiH}_{4}$ and a variable $\mathrm{C}_{2} \mathrm{H}_{4}$ flow. The $\mathrm{C}_{2} \mathrm{H}_{4}$ flow was varied according to: $0.375 \mathrm{sccm}$ for $3 \mathrm{hr}$ (Region I), $0.5 \mathrm{sccm}$ for $3 \mathrm{~h}$ (Region II), and $0.75 \mathrm{sccm}$ for $3 \mathrm{~h}$ (Region III). The change in $\mathrm{N}$ content with $\mathrm{C}$ source supply is very apparent from the abrupt changes that occur in the $\mathrm{N}$ depth profile. A flow of $0.75 \mathrm{sccm} \mathrm{C}_{2} \mathrm{H}_{4}$ resulted in the incorporation of $\mathrm{N}$ at the detection limit for $\mathrm{N} \quad \approx 5$ $\times 10^{15} \mathrm{~cm}^{-3}$ ) in the SIMS system.

Several films of both $6 \mathrm{H}-\mathrm{SiC}$ (grown on vicinal $6 \mathrm{H}-\mathrm{SiC}$ )

TABLE II. Electrical properties of undoped $6 \mathrm{H}-\mathrm{SiC}$ films.

\begin{tabular}{lccc}
\hline \hline & $C-V$ measurement & \multicolumn{2}{c}{ Hall measurement } \\
\hline $\mathrm{C}_{2} \mathrm{H}_{4}$ flow $(\mathrm{sccm})$ & $N_{D}-N_{A}\left(\mathrm{~cm}^{-3}\right)$ & $n\left(\mathrm{~cm}^{-3}\right)$ & $\mu_{n}\left(\mathrm{~cm}^{2} \mathrm{~V}^{-1} \mathrm{~s}^{-1}\right)$ \\
0.375 & $4.3 \times 10^{15}$ & $2.2 \times 10^{15}$ & 371 \\
0.5 & $1.3 \times 10^{15}$ & $5.4 \times 10^{14}$ & 398 \\
0.75 & $7.1 \times 10^{14}$ & $3.6 \times 10^{14}$ & 434 \\
\hline \hline
\end{tabular}

and $3 \mathrm{C}-\mathrm{SiC}$ (grown on on-axis $6 \mathrm{H}-\mathrm{SiC}$ ) were also grown at $1400{ }^{\circ} \mathrm{C}$ using the three different $\mathrm{C}_{2} \mathrm{H}_{4}$ flow rates noted above. The carrier concentration and mobility results from $C-V$ and Hall-effect characterization are listed in Tables II and III. The increase in the impurity and electron concentrations with decreasing $\mathrm{C}_{2} \mathrm{H}_{4}$ input confirmed the "sitecompetition model' for $N$ incorporation by MBE.

Despite the fact that unintentionally doped $\mathrm{SiC}$ films were $n$-type as grown, $n$-type doping was studied in order to establish a controllable electron population within the grown films. In order to perform this study, $\mathrm{N}$ was introduced into the $\mathrm{SiC}$ lattice during growth of the $\mathrm{SiC}$ epilayers. Since the quantity of $\mathrm{N}$ incorporated into the $\mathrm{SiC}$ lattice from residual gas molecules in the growth reactor was not a concern when $n$-type doping was performed, the reactant mixture with the lowest total input of source gases $\left(0.75 \mathrm{sccm} \mathrm{SiH}_{4}, 0.375\right.$ sccm $\mathrm{C}_{2} \mathrm{H}_{4}$, and $5 \mathrm{sccm} \mathrm{H}_{2}$ ) was chosen. Donor doping was performed in situ at $1400{ }^{\circ} \mathrm{C}$ on monocrystalline $6 \mathrm{H}$ - and $3 \mathrm{C}$-SiC using both the $\mathrm{H}_{2}$-diluted $\mathrm{NH}_{3}$ and pure $\mathrm{N}_{2}$. Doping between $5 \times 10^{15}$ and $8 \times 10^{17} \mathrm{~cm}^{-3}$ was achieved using the $\mathrm{NH}_{3} / \mathrm{H}_{2}$ mixture; $1 \times 10^{18}-4 \times 10^{19} \mathrm{~cm}^{-3}$ with the $\mathrm{N}_{2}$ additions. Figures 2 and 3 show the electron mobility as a function of electron concentration in the close-packed plane for $6 \mathrm{H}-\mathrm{SiC}(0001)$ and $3 \mathrm{C}-\mathrm{SiC}(111)$ at room temperature for both undoped and doped films.

Epilayers of $6 \mathrm{H}$ - and 3C-SiC were doped $p$-type by incorporating $\mathrm{Al}$ in the growing epilayers. All growth experiments were performed at $1450{ }^{\circ} \mathrm{C}$ using $0.75 \mathrm{sccm} \mathrm{SiH}_{4}$, $0.75 \mathrm{sccm} \mathrm{C}_{2} \mathrm{H}_{4}$, and $5 \mathrm{sccm} \mathrm{H}_{2}$. The higher $\mathrm{C}_{2} \mathrm{H}_{4}$ flow rate was used to take advantage of the site-competition process which resulted in a decrease in the concentration of background $\mathrm{N}$, a compensating impurity in $p$-type $\mathrm{SiC}$. The higher temperature was used in an attempt to aid in dopant activation. Acceptor doping between $2 \times 10^{15}$ and 8 $\times 10^{18} \mathrm{~cm}^{-3}$ was achieved. Figures 4 and 5 show the hole mobility as a function of hole concentration in the close-

TABLE III. Electrical properties of undoped 3C-SiC films.

\begin{tabular}{cccc}
\hline \hline & $C-V$ measurement & \multicolumn{2}{c}{ Hall measurement } \\
\hline $\mathrm{C}_{2} \mathrm{H}_{4}$ flow $(\mathrm{sccm})$ & $N_{D}-N_{A}\left(\mathrm{~cm}^{-3}\right)$ & $n\left(\mathrm{~cm}^{-3}\right)$ & $\mu_{n}\left(\mathrm{~cm}^{2} \mathrm{~V}^{-1} \mathrm{~s}^{-1}\right)$ \\
\hline 0.375 & $9.1 \times 10^{15}$ & $5.3 \times 10^{15}$ & 608 \\
0.5 & $3.7 \times 10^{15}$ & $9.8 \times 10^{14}$ & 681 \\
0.75 & $9.2 \times 10^{14}$ & $4.6 \times 10^{14}$ & 772 \\
\hline \hline
\end{tabular}




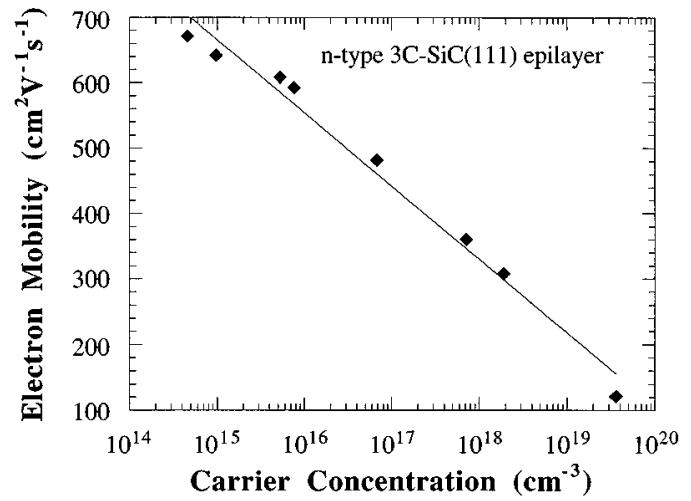

FIG. 3. Electron mobility vs carrier concentration for $n$-type 3C-SiC(111) epilayers. Measurements were performed at room temperature. The solid line is a guide for the eye.

packed plane for $6 \mathrm{H}-\mathrm{SiC}(0001)$ and $3 \mathrm{C}-\mathrm{SiC}(111)$ measured at room temperature.

In summary, monocrystalline thin films of $3 \mathrm{C}$ - and $6 \mathrm{H}-$ $\mathrm{SiC}$ have been grown on on-axis and vicinal $\alpha(6 \mathrm{H})$ $\mathrm{SiC}(0001)$ substrates, respectively, by GSMBE at 1400$1450{ }^{\circ} \mathrm{C}$ using a $\mathrm{SiH}_{4}-\mathrm{C}_{2} \mathrm{H}_{4}-\mathrm{H}_{2}$ gas mixture. The concentration of $\mathrm{N}$ in the epilayers was found to depend directly on the $\mathrm{SiH}_{4} / \mathrm{C}_{2} \mathrm{H}_{4}$ ratio. An undoped $6 \mathrm{H}-\mathrm{SiC}$ epilayer with an electron concentration of $3.6 \times 10^{14} \mathrm{~cm}^{-3}$ and mobility of $434 \mathrm{~cm}^{2} \mathrm{~V}^{-1} \mathrm{~s}^{-1}$ was produced. This mobility measurement is believed to be the highest reported for this polytype and, perhaps, is an indication of the high purity achieved in $6 \mathrm{H}-\mathrm{SiC}$ epilayers by GSMBE. Epilayers could be doped $n$-or $p$-type in situ by adding $\mathrm{N}$ or Al.

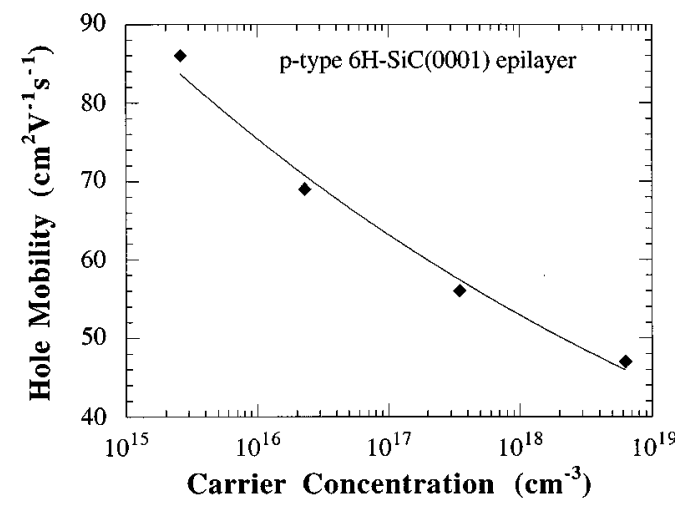

FIG. 4. Electron mobility vs carrier concentration for $p$-type $6 \mathrm{H}-\mathrm{SiC}(0001)$ epilayers. Measurements were performed at room temperature. The solid line is a guide for the eye.

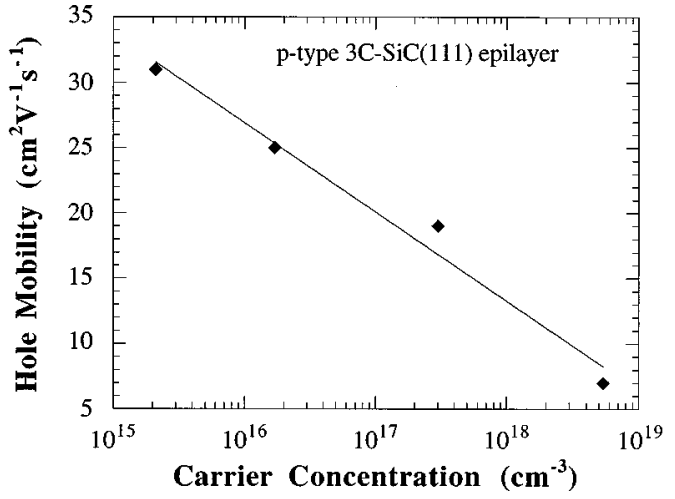

FIG. 5. Electron mobility vs carrier concentration for $p$-type 3C-SiC(111) epilayers. Measurements were performed at room temperature. The solid line is a guide for the eye.

The authors acknowledges The Office of Naval Research for the sponsorship under Contract No. N00014-92-J-1500, Cree Research Inc. for providing the $\mathrm{SiC}$ substrates, R. G. Wilson of Hughes Research Laboratories and Z. Radzimski of NCSU for SIMS analysis and K. Järrendahl of NCSU for careful review of this manuscript.

${ }^{1}$ G. R. Fisher and P. Barnes, Philos. Mag. B 61, 217 (1990).

${ }^{2}$ R. S. Kern, S. Tanaka, L. B. Rowland, and R. F. Davis, J. Cryst. Growth (submitted).

${ }^{3}$ S. Kaneda, Y. Sakamoto, T. Mihara, and T. Tanaka, J. Cryst. Growth 81, 536 (1987).

${ }^{4}$ L. B. Rowland, S. Tanaka, R. S. Kern, and R. F. Davis, in Amorphous and Crystalline Silicon Carbide IV, edited by C. Y. Yang, M. M. Rahman, and G. L. Harris (Springer, Berlin, 1992), p. 84.

${ }^{5}$ N. Kuroda, K. Shibahara, W. Yoo, S. Nishino, and H. Matsunami, Extended Abstracts of the 19th Conference on Solid State Devices and Materials, 1987, p. 227.

${ }^{6}$ K. Shibahara, N. Kuroda, S. Nishino, and H. Matsunami, Jpn. J. Appl. Phys., Part 2 26, L1815 (1987).

${ }^{7}$ H. S. Kong, J. T. Glass, and R. F. Davis, J. Appl. Phys. 64, 2672 (1988).

${ }^{8}$ J. A. Powell, D. J. Larkin, L. G. Matus, W. J. Choyke, J. L. Bradshaw, L. Henderson, M. Yoganathan, J. Yang, and P. Pirouz, Appl. Phys. Lett. 56, 1442 (1990).

${ }^{9}$ R. S. Kern, Ph.D. thesis, North Carolina State University, Raleigh, NC, 1996

${ }^{10}$ D. J. Larkin, P. G. Neudeck, J. A. Powell, and L. G. Matus, Appl. Phys. Lett. 65, 1659 (1994).

${ }^{11}$ D. J. Larkin, P. G. Neudeck, J. A. Powell, and L. G. Matus, in Silicon Carbide and Related Materials, edited by M. G. Spencer, R. P. Devaty, J. A. Edmond, M. A. Khan, R. Kaplan, and M. Rahman (Institute of Physics, Bristol, 1994), p. 51.

${ }^{12}$ D. J. Larkin, S. G. Sridhara, R. P. Devaty, and W. J. Choyke, J. Electron. Mater. 24, 289 (1995)

${ }^{13}$ D. J. Larkin, in Silicon Carbide and Related Materials-1995, edited by S. Nakashima, H. Matsunami, S. Yoshida, and H. Harima (Institute of Physics, Bristol, 1995), p. 218. 